\title{
Erratum to: Tuberculosis is still the most Common \\ Cause of Mediastinal and Intra-abdominal Lymphadenopathy by EUS-FNA in India
}

\author{
Manas Kumar Behera ${ }^{1}$ Jimmy Narayan ${ }^{2}$ Shobhit Agarwal ${ }^{2}$ Debakanta Mishra² \\ Pruthvi Reddy ${ }^{2}$ Ayaskanta Singh ${ }^{2}$ Girish Kumar Pati ${ }^{2}$ Manoj Kumar Sahu ${ }^{2}$ \\ ${ }^{1}$ Department of Hepatology, SCB Medical College, Cuttack, Orrisa, \\ India \\ ${ }^{2}$ Department of Gastroenterology, Institute of Medical Sciences \& \\ SUM Hospital, Siksha O Anusandhan Deemed to be University, K8, \\ Kalinganagar, Bhubaneswar, Orissa, India \\ Address for correspondence Manoj Kumar MD, DM Sahu, \\ Department of Gastroenterology, Institute of Medical Sciences \\ \& SUM Hospital, Siksha O Anusandhan Deemed to be University, \\ K8, Kalinganagar, Bhubaneswar, Orissa, 751003, India \\ (e-mail: manojsahu@soa.ac.in).
}

J Digest Endosc 2021;12:133-137.

\section{Erratum}

DOI https://doi.org/ $10.1055 / \mathrm{s}-0042-1743293$ ISSN 0976-5042
The authors of the above-mentioned article have informed the Publisher about change in first author's affiliations. The article was published in volume 12, issue 3 . The doi of the original article is: 10.1055/s-0041-1739965.

The corrected affiliations should be read as:

1'Department of Hepatology, SCB Medical College, Cuttack, Orrisa, India

${ }^{2}$ Department of Gastroenterology, Institute of Medical Sciences \& SUM Hospital, Siksha O Anusandhan Deemed to be University, K8, Kalinganagar, Bhubaneswar, Orissa, India (c) 2021. Society of Gastrointestinal Endoscopy of India. Society of Gastrointestinal Endoscopy of India. This is an open access article published by Thieme under the terms of the Creative Commons Attribution-NonDerivative-NonCommercial-License, permitting copying and reproduction so long as the original work is given appropriate credit. Contents may not be used for commercial purposes, or adapted, remixed, transformed or built upon. (https://creativecommons.org/licenses/by-nc-nd/4.0/).

Thieme Medical and Scientific Publishers Pvt. Ltd. A-12, 2nd Floor, Sector 2, Noida-201301 UP, India 